\title{
Isolation and Identification of Predominant Lactic Acid Bacterial Flora From Oat Bran Sourdough and Their Antifungal Ability
}

\author{
Tahereh Masoomshahi ${ }^{1}$, Jalal Ehsani ${ }^{1 *}$, Maryam Ebrahimi ${ }^{1}$
}

1. Food, Drug, Natural Products Health Research Centre, Golestan University of Medical Sciences, Gorgan, Iran

\begin{abstract}
Background: The widespread consumption of industrial fermented products instead of traditional products leads to the loss of various lactic acid bacteria ( $L A B)$, especially the strains producing bioactive compounds. The present study aimed to isolate and molecularly identify $L A B$ and investigate their antifungal impact on Aspergillus niger growth.
\end{abstract}

Materials \& Methods: Oat bran was purchased from the Gorgan city market in 2019 and sourdough was prepared. Afterwards, bacteria were isolated and identified in the Microbiology Laboratory of Golestan University of Medical Sciences, Gorgan, Iran. Next, the antifungal activity of $L A B$ and their supernatant against $A$. niger was investigated. Finally, the identification of the cellfree supernatant of LAB was completed using gas chromatography-mass spectrometry.

Results: Findings of the current study demonstrated that Lactobacillus brevis and Lactobacillus sakei had the highest inhibitory effects of $30.25 \%$ and $18.47 \%$ against $A$. niger, respectively. Moreover, the minimum inhibitory concentration of $L$. brevis and $L$. sakei supernatants against $A$. niger was found as $3 \%$. We observed that the greater effect of the supernatant of $L$. brevis could be due to the presence of ester, phenolic, and barbiturate compounds.

Conclusion: According to our results, dominant LAB from oat bran sourdough, as well as their cultured pellets have suitable antifungal potential against $A$. niger. Therefore, these bacteria can be used as a starter culture or co-culture in the fermentation products process, such as sourdough to decrease fungal contamination.

Keywords: Antifungal effect, Lactic acid bacteria, Sourdough

Received: 2019/11/05; Accepted: 2020/05/15; Published Online: 2020/09/26

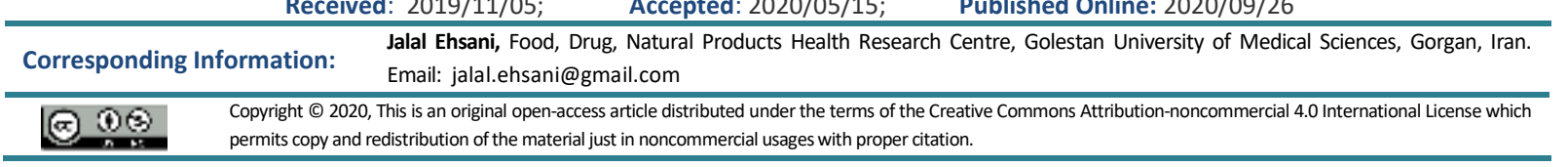

Use your device to scan and read the article online

Masoom shahi T, ehsani J, Ebrahimi M. Isolation and identification of the predominant lactic acid

bacteria (LAB) flora from oat bran sourdough and investigation of their antifungal ability. Iran J Med

Microbiol. 2020; 14 (5) :408-424

Download citation: BibTeX | RIS | EndNote | Medlars | ProCite | Reference Manager | RefWorks

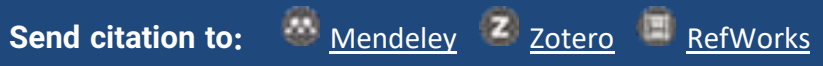

\section{Introduction}

The spoilage of bakery products is mainly caused by the growth of molds. Aspergillus, which grows in various bakery products, produces aflatoxin leading to serious health problems in people and irreversible economic damage. Food contamination with aflatoxin is a common problem in the tropical and subtropical regions of the world, especially in developing countries (1). Aflatoxin B1 is considered to be the most toxic aflatoxin and the most potent liver carcinogen produced by some species of the genus Aspergillus. The successful control of mold growth can be regarded as one of the most critical steps to prevent cancer (2).

During the last two decades, researchers have paid great attention to the use of microorganisms with antagonistic and harmless effects. These microorganisms are known as the major biological methods for food preservation that reduce Aspergillus growth and aflatoxins (3). Lactic acid bacteria (LAB) can produce some antimicrobial compounds, including organic acids, 
diacetyl, acetone, hydrogen peroxide, antifungal peptides, and bacteriocins, which are effective against a wide range of pathogenic and spoilage-causing fungi (4).

Oats (Avena sativa L.), commonly known as Oates, belong to the Gramineae family, which have barley-like fruits with two sharp-edged points. Oat species are kind of weeds that are cultivated in different parts of the world, even in Iran due to their compatibility with different climates $(5,6)$. The sourdough obtained from this grain can be considered as one of the remarkable sources of LAB.

There are numerous studies on the isolation and identification of LAB from yeast, as well as on the antifungal activity of these isolates. For example, Demirbas et al. (2017) isolated 15 LAB from a traditional sourdough sample and examined their antifungal properties. They showed that Lactobacillus paraplantarum and Lactobacillus paralimentarius had the highest antifungal potential against Penicillium chrysogenum and Aspergillus niger (7). According to a study conducted by Sadeghi et al. (2016), Pediococcus pentosaceus isolated from the sourdough of barley flour and the supernatant obtained by cultivating this lactic isolate against Aspergillus had antifungal properties (8).

The possibility of finding isolates with unique capabilities has always augmented the application of the new methods of identifying and determining the functional properties of LAB in the less studied ecosystems. Fermented food products, such as fermented bran are ideal habitats for LAB. Consequently, the present study aimed to isolate and identify dominant lactic isolates in the sourdough of oat bran and investigate their antifungal influence on $A$. niger.

\section{Materials and Methods}

This experimental study was conducted in 2019 in the Microbiology Laboratory of the Deputy of Food and Drug Administration in Golestan University of Medical Sciences, Gorgan, Iran. First, barley bran flour was purchased from the suppliers of Gorgan city. Following the determination of some of its characteristics, namely moisture content, protein, and ash based on the previously documented procedures (9), sourdough was prepared.

\section{Sourdough Preparation}

In order to prepare sourdough from oat bran flour, based on the efficiency of dough [(dough/flour)×100], respectively, 450 and 160 . Supplying of the proper ratio was followed by fermenting the prepared sourdough at $37^{\circ} \mathrm{C}$ for $24 \mathrm{~h}$. Next, $20 \%$ of sourdough was added to the water and flour mixture every single day (i.e., inoculation) and was left in the oven at $37^{\circ} \mathrm{C}$ for $24 \mathrm{~h}(10)$.
Isolation and Primary Identification of Lactic Acid

\section{Bacteria}

First, $10 \mathrm{~g}$ of each sourdough sample was transferred to $90 \mathrm{~mL}$ of Ringer's solution under sterile conditions. Afterwards, a serial dilution of the solution was made in eight tubes containing $9 \mathrm{~mL}$ of sterile Ringer's solution until reaching the dilution of $10^{9}$. Two replications of pour culture were completed on deMan, Rogosa, and Sharpe (MRS) agar from the obtained dilutions and the plates were incubated in a $\mathrm{CO}_{2}$ incubator at $37^{\circ} \mathrm{C}$ for 48 $\mathrm{h}$ in the presence of $10 \% \mathrm{CO}_{2}$.

In the next step, several colonies were selected from each plate based on the differences in the morphological characteristics of colonies (e.g., color, shape, being convex or concave, and being superficial or deep) and linear culture was performed for purification and propagation on MRS agar medium. Isolation was followed by the initial detection of lactic isolates using biochemical methods, such as catalase test and gram staining (10).

\section{Identification of Lactic Acid Bacteria by Polymerase Chain Reaction}

In addition to the initial isolation and identification of lactic isolates using biochemical and morphological methods, including catalase test and gram staining, LAB identification using polymerase chain reaction (PCR) was conducted with specific primers (11). At this stage, DNA extraction was performed by GeneAll Commercial Kit (South Korea) according to the manufacturer's instructions. The applied primer and PCR reaction conditions were selected according to the method of Young et al. (2012).

The initial evaluation of PCR products by electrophoresis was completed on $1.5 \%$ agarose gel applying a voltage of $90 \mathrm{~V}$ for $40 \mathrm{~min}$. Following electrophoresis and initial approval, PCR products were sent to Bioneer Corporation, South Korea for sequencing. Afterwards, the obtained sequences were compared with the sequences in the National Center for Biotechnology Information (NCBI) using Blast software and the lactic isolates were identified in terms of genius and species (11).

\section{Antifungal Activity of Lactic Isolates}

In order to investigate the antifungal activity of lactic isolates, two lines of $3 \mathrm{~cm}$ were cultured at a distance of $2 \mathrm{~cm}$ from the activated culture on MRS agar medium. Following incubation for $72 \mathrm{~h}$ at $37{ }^{\circ} \mathrm{C}$ in $10 \%$ $\mathrm{CO}_{2}, 5 \mathrm{~mL}$ of yeast extract glucose chloramphenicol (YGC) medium containing mold spores $\left(10^{4} \mathrm{spore} / \mathrm{mL}\right)$ was added to the plate surface, and it was incubated at 37 으 under aerobic conditions. The diameter of the mold colony was measured daily utilizing ImageJ software until the control plate (i.e., MRS agar and a layer of YGC medium containing mold spores) was 
completely covered with mold. The lactic isolates that inhibited mold growth were selected (12).

\section{Preparation of Cell-free Supernatants}

The lactic isolate suspension with $\mathrm{OD}_{600}=1$ was centrifugation at $10000 \mathrm{rpm}$ and $4 \stackrel{\mathrm{O}}{\mathrm{C}}$ for $5 \mathrm{~min}$ and the cell-free supernatant was isolated. Afterwards, the antimicrobial effect of organic acids was inhibited and the neutral cell-free supernatant was obtained using $0.1 \mathrm{~N} \mathrm{NaOH}$ and achieving a $\mathrm{pH}$ of 6.5 , which was the initial $\mathrm{pH}$ of the culture medium (13).

\section{Antifungal Activity of the Supernatants of Lactic Isolates}

To determine the antifungal effect of the supernatant, $1 \%-10 \%$ of the cell-free supernatant was added to the sterile YGC medium (45ㅇ) and it was poured into the plate. The control sample included a YGC medium with $10 \%$ sterile distilled water. Following the coagulation of the culture medium, $3 \mu \mathrm{L}$ of fungal spore containing $10^{4} \mathrm{spore} / \mathrm{mL}$ was placed as dots on the surface and at the central part of the plate. The plates were placed under aerobic conditions at $260 \mathrm{C}$ and the mold growth rate was measured daily until the mold in the control sample completely covered the plate surface. Lactic isolate with the lowest minimum inhibitory concentration (MIC) (i.e., the minimum concentration of supernatant that significantly reduced mold growth, compared to the control sample) on the examined molds was selected (14).

\section{Compounds of the Cell-free Supernatant of Lactic} Isolates

The supernatant obtained from the lactic isolate with the highest level of antifungal activity was dried by freeze-dryer. Next, $18 \mathrm{~g}$ of the obtained powder was dissolved in $100 \mathrm{ml}$ of sterile distilled water. A total of $20 \mathrm{ml}$ of the resultant solution was added to the ethyl acetate solvent in a ratio of $1: 3$ and was shaken continuously by hand for $15 \mathrm{~min}$. During this procedure, all organic compounds were transferred to the ethyl acetate phase and this phase was placed on the surface of the aqueous phase.

At this stage, the mentioned phase was slowly isolated from the aqueous phase and this process was repeated twice for better extraction of organic compounds. Ethyl acetate was then evaporated using a rotary evaporator at 65 을 $\mathrm{C}$ under vacuum conditions and the residual containing organic compounds was isolated (14). To identify the organic compounds, the samples were finally sent to the Chemistry and Chemical Engineering Research Institute of Iran under refrigerated conditions. The compounds of the cell-free supernatant of the lactic isolates were identified using gas chromatography/mass spectrometry (GC/MS) (Agilent, model 7890B, USA). The carrier gas (mobile phase) of the GC/MS was helium with a flow rate of 1 $\mathrm{mL} / \mathrm{min}$ and the column (fixed phase) was Agilent Hp5Ms with a length of $30 \mathrm{~m}$, an internal diameter of $0.25 \mathrm{~mm}$, and a thickness of $0.25 \mu \mathrm{m}$.

\section{Statistical Analysis}

The data were statistically analyzed using SPSS software version 16 and Excel version 2007. All tests were performed with three repetitions in a completely randomized design. The means were compared by the LSD test at a $5 \%$ level.

\section{Results}

\section{Characteristics of Raw Materials and Changes in $\mathrm{pH}$ and Titratable Acidity}

The results of the chemical tests of oat bran flour, including the percentage of moisture, protein, and ash are given in Table 1.

Table 1. Chemical characteristics of oat bran flour

\begin{tabular}{|ccc|}
\hline Moisture & Ash & Protein \\
\hline $10.24 \pm 0.04$ & $2.74 \pm 0.01$ & $13.68 \pm 0.01$
\end{tabular}

Moreover, the trend of variations in the titratable acidity of sourdough obtained through inoculation during four consecutive days is shown in Table 2. As could be seen, $\mathrm{pH}$ decreased with fermentation time and the titratable acidity of the oat bran sourdough augmented. In addition, a comparison of the sourdough titratable acidity values during 72 consecutive hours of inoculation process revealed a significant difference $(P<0.05)$ after $48 \mathrm{~h}$, while there was no significant difference between $48 \mathrm{~h}$ and $72 \mathrm{~h}(P<0.05)$.

Table 2. $\mathrm{pH}$ and titratable acidity changes during the fermentation of oat bran sourdough

\begin{tabular}{|ccc|}
\hline Time & pH & Titrable acidity $\left(^{\mathrm{o}} \mathbf{D}\right)$ \\
\hline 0 & $6.42 \pm 0.05^{\mathrm{a}}$ & $16.45 \pm 0.35^{\mathrm{a}}$ \\
\hline 24 & $6.02 \pm 0.02^{\mathrm{a}}$ & $20.96 \pm 1.15^{\mathrm{b}}$ \\
\hline 48 & $4.92 \pm 0.05^{\mathrm{b}}$ & $31.45 \pm 0.4^{\mathrm{c}}$ \\
\hline $\mathbf{7 2}$ & $4.58 \pm 0.06^{\mathrm{c}}$ & $33.35 \pm 1.25^{\mathrm{c}}$ \\
\hline
\end{tabular}




\section{Isolation and Identification of Lactic Isolates}

In order to identify the predominant lactic isolates after 3 days of repeating the sourdough inoculation process, the LAB of each sourdough were isolated as described. The findings of the initial tests confirmed that the isolates were gram-positive and catalasenegative. Furthermore, according to Figure 1, the gel electrophoresis of PCR products confirmed the amplification of a target sequence of $1500 \mathrm{bp}$. The comparison of sequenced products with the sequences in World Gene Bank helped to identify the isolates L. brevis, L. sakei NBRC 15893, and Enterococcus hirae ATCC9790 with 99\%, 95\%, and 97\% similarity, respectively. Moreover, $P$. pentosaceus ATCC 20336 isolate was found to have a similarity of $92 \%$.

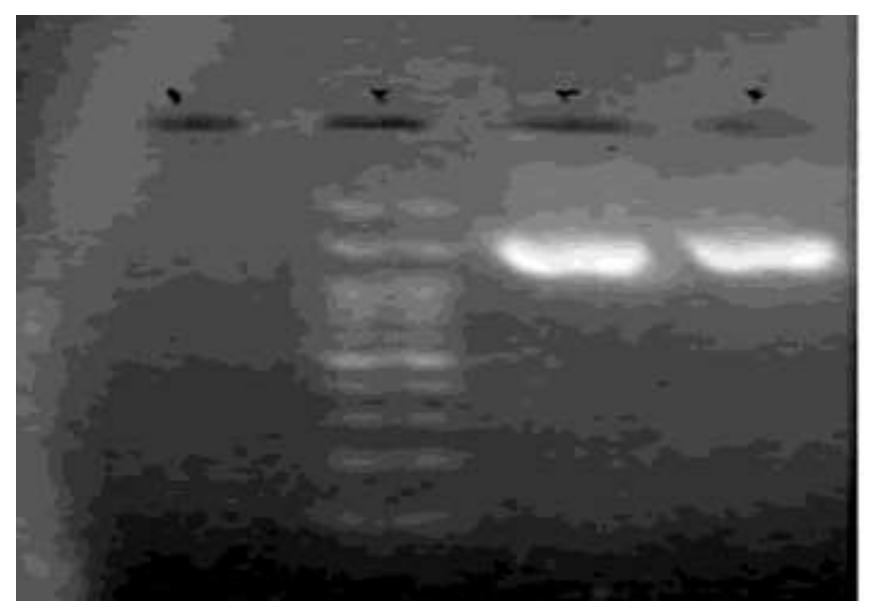

Figure 1. Gel electrophoresis of PCR products and a specific primer with the target sequence of 1500 bp to identify the lactic isolate (line) in the vicinity of the marker of $100 \mathrm{bp}$ (Line 2), positive control samples containing DNA from pure Lactococcus lactis culture (PTCC 1336) (Line 3), and negative or bactericidal control (Line 1)

\section{Effect of Lactic Isolates on the Growth of $\boldsymbol{A}$. niger}

The antifungal activity of lactic isolates against $A$. niger is demonstrated in Table 3. According to Table 3,
A. niger covered the whole surface of the control plate at the end of the fourth day, while the growth of the fungi in the presence of lactic isolates varied from $69.75 \%-100 \%$.

Table 3. Growth percentage of $A$. niger in the presence of lactic isolates during 4 days of incubation

\begin{tabular}{|cccc|}
\hline Sample & \multicolumn{1}{c|}{ Day } & 3 \\
\hline Control & 1 & 2 & $45.32 \pm 2.11^{\mathrm{Ab}}$ \\
\hline L. brevis & $10.56 \pm 1.42^{\mathrm{Ad}}$ & $56.05 \pm 5.86^{\mathrm{Ac}}$ & $20.25 \pm 4.8^{\mathrm{Eb}}$ \\
\hline L. sakei & $0.0 \pm 0.0^{\mathrm{Bc}}$ & $0.0 \pm 0.0^{\mathrm{Cc}}$ & $37.33 \pm 1.59^{\mathrm{Db}}$ \\
\hline E. hirae & $0.0 \pm 0.0^{\mathrm{Bd}}$ & $7.1 \pm 2.41^{\mathrm{Dc}}$ & $89.75 \pm 3.07^{\mathrm{Ca}}$ \\
\hline P. pentosaceous & $0.0 \pm 0.0^{\mathrm{Bd}}$ & $51.03 \pm 5.02^{\mathrm{Ac}} \pm 4.12^{\mathrm{Ba}}$ & $86.48 \pm 5.76^{\mathrm{Bb}}$ \\
\hline$*$ Simila & $29.45 \pm 2.35^{\mathrm{Bc}}$ & $75.44 \pm 3.91^{\mathrm{Cb}}$ \\
\hline
\end{tabular}

* Similar lowercase letters in each row indicate that there is no significant difference between the means $(P<0.05)$

* Similar capital letters in each column indicate that there is no significant difference between the means $(P<0.05)$

According to the results presented in Table 3 , at the end of the fourth day, two of the four studied lactic isolates did not impose a significant impact on the reduction of $A$. niger growth, compared to the control plate. However, L. brevis and $L$. sakei had the highest inhibitory effects of $30.25 \%$ (Figure 2) and $18.47 \%$ against $A$. niger, respectively. Therefore, the antifungal influence of their supernatants was investigated.

According to the results of Table 4 and Figure 3 , the MIC of the raw supernatants of L. brevis and L. sakei against $A$. niger was $3 \%$ with $L$. brevis having a higher inhibitory potential than $L$. sakei at all three supernatant levels. 


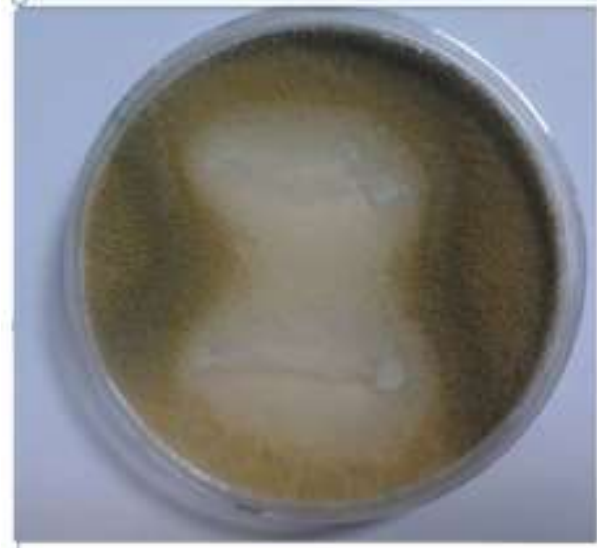

A

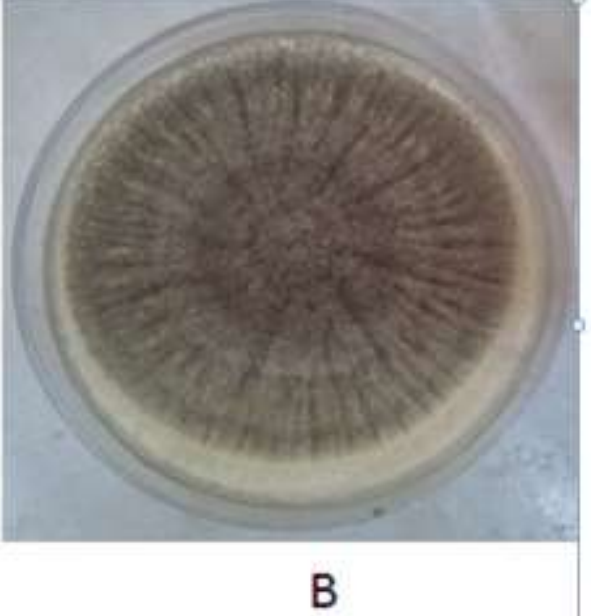

B

Figure 2. Antifungal effect of $L$. brevis (A) against $A$. niger and comparison with the control sample (B)

Table 4. Growth percentage of $A$. niger in the presence of the raw supernatant of lactic isolates

\begin{tabular}{|ccc|}
\hline Raw supernatant $(\%)$ & L. brevis & \multicolumn{1}{c}{ sakei } \\
\hline Control $(0)$ & $100 \pm 0.0^{\mathrm{Aa}} \pm 0.0^{\mathrm{Aa}}$ & $100 \pm 0.0^{\mathrm{Aa}}$ \\
\hline 1 & $100 \pm 0.0^{\mathrm{Aa}}$ & $100 \pm 0.0^{\mathrm{Aa}}$ \\
\hline 2 & $100 \pm 0.0^{\mathrm{Aa}}$ & $97.65 \pm 2.05^{\mathrm{Aa}}$ \\
\hline 3 & $66.33 \pm 8.78^{\mathrm{Bb}}$ & $94.18 \pm 2.16^{\mathrm{Ab}}$ \\
\hline 4 & $47.93 \pm 5.35^{\mathrm{Bc}}$ & $89.72 \pm 3.55^{\mathrm{Ac}}$ \\
\hline 5 & $34.14 \pm 8.65^{\mathrm{Bc}}$ & \\
\hline
\end{tabular}

* Similar lowercase letters in each column indicate that there is no significant difference between the means $(P<0.05)$

* Similar capital letters in each row indicate that there is no significant difference between the means $(P<0.05)$

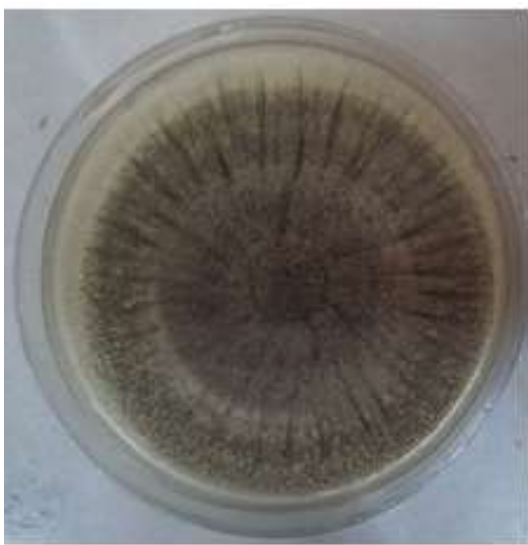

A

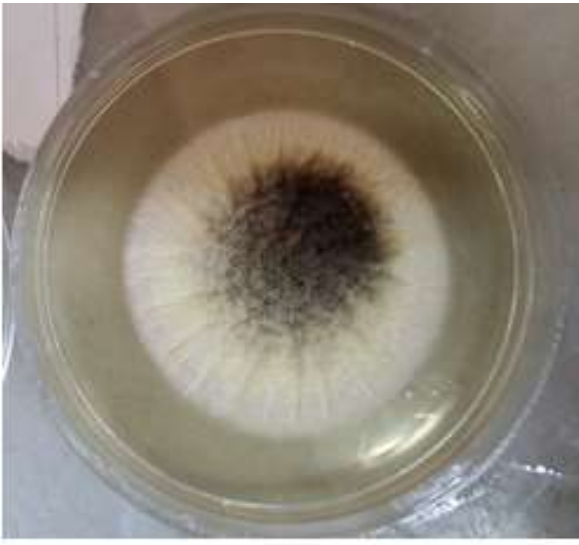

B

Figure 3. A. niger growth in the presence of $3 \%$ L. brevis supernatant (B), compared to the control sample (A)

\section{Raw Supernatant Organic Compounds}

As described, our findings indicated that $L$. brevis raw supernatant had a more remarkable antifungal effect. Consequently, the compounds of the raw supernatant of this bacterium were studied and identified using GC/MS. The results revealed 14 compounds in raw supernatants, such as fatty acids, esters, phenols, and barbiturates (Table 5). 
Table 5. Organic compounds identified in raw supernatant

\begin{tabular}{|c|c|c|c|}
\hline & Compound & Group & Retention time \\
\hline 1 & Lactic acid, 3-phenyl-methyl ester & Ester & 13.691 \\
\hline 2 & n-Decanoic acid & Fatty acid & 13.883 \\
\hline 3 & Benzenepropanoic acid, a-hydroxy-methyl ester & Ester & 15.231 \\
\hline 4 & Acetic acid & Fatty acid & 19.754 \\
\hline 5 & 5-Ethyl-5-isopropylpyrimidine-2,4,6(1H,3H,5H)-trione & Barbiturates & 20.202 \\
\hline 6 & Pentadecanoic acid & Fatty acid & 20.458 \\
\hline 7 & Palmitic acid & Fatty acid & 20.914 \\
\hline 8 & 1-Mono-linolein & Fatty acid & 22.373 \\
\hline 9 & 9-Hexadecenoic acid & Fatty acid & 22.652 \\
\hline 10 & Decanedioic acid dibutyl ester & Ester & 24.343 \\
\hline 11 & Hexanedioic acid mono(2-ethylhexyl) ester & Ester & 24.544 \\
\hline 12 & Octadecanoic acid 9,10-dihydroxy-methyl ester & Ester & 24.778 \\
\hline 13 & N-Formyl-D-phenylalanine & Phenol & 25.109 \\
\hline 14 & 5-Ethenyl-5-pentan-2-yl-1,3-diazinane-2,4,6-trione (vinilbital) & Barbiturates & 26.882 \\
\hline
\end{tabular}

\section{Discussion}

Developed countries have seriously explored and recognized the novel species of $L A B$ for industrial applications and have used these bacteria extensively for about a century. However, Iran has only addressed this subject during recent years. Therefore, considering many unknown ecosystems, especially microbial, fundamental research should be performed as the first step toward creating an acceptable microbial bank from the $L A B$ in the pristine regions of Iran. Following the research examination, these isolates can be used industrially.

This group of bacteria can produce antimicrobial compounds, such as organic acids, diacetyl, acetone, hydrogen peroxide, antifungal peptides, and bacteriocins, which are effective against a wide range of pathogenic and spoilage-causing fungi (8). In the meantime, oat bran is considered as a source of soluble dietary fiber, which has long been used in breakfast cereals or bakery products. In addition, sourdough is regarded as one of the most important sources of LAB. Nowadays, the microbial flora of fermented products and cultivation-based methods is identified and classified using molecular techniques, including PCR (15).

In the current study, four types of $L A B$, namely $L$. Brevis, L. sakei, E. hirae, and P. pentosaceus were isolated from the sourdough of oat bran and were identified by some primary tests, such as gram staining and catalase test followed by the sequencing of PCR products. Similar to the present study, Gobbetti et al. (1998) managed to isolate L. brevis, L. plantarum, and
L. fermentum from a sample of wheat flour sourdough as the dominant isolates (16). Holzapfel and Wood (1995) reported L. brevis and L. fermentum as the dominant bacteria in sourdough (17).

Katina et al. (2012) in another investigation encountered a predominantly different microbial population of obligate heterofermentative species, such as Weissella cibaria and $W$. confuse during the spontaneous fermentation of wheat bran (18). Simsek et al. (2006) evaluated 60 sourdough samples collected from traditional Turkish bakeries. They isolated L. acidophilus, L. plantarum, L. viridescens, $L$. brevis, L. delbrueckii, L. sakei, and various other species of Lactobacillus and Pediococcus. In a study conducted on the biodiversity of LAB in French sourdough (19), Robert et al. (2009) found that $38 \%$ of the isolated LAB belonged to Pediococcus genus (20).

Concerning the antifungal activity of lactic isolates obtained from the sourdough of barley bran against $A$. niger, we found that L. brevis and $L$. sakei isolates had higher inhibitory potential. The inhibitory impact of this bacteria on the growth of the studied fungus can be attributed to the influence of produced metabolites on germination and fungal growth, compared to the control sample (21).

Our results are consistent with the findings of Rejiniemon et al. (2015) who showed that lactic acid isolates obtained from malt fermentation products can significantly inhibit the growth of Aspergillus, Penicillium, and Fusarium by producing phenyllactic acid and 4-hydroxy phenyllactic acid (22). Diase et al. (2014) evaluated the antifungal effect of $L$. brevis as an 
inhibitor of Aspergillus growth. Their findings suggested that lactic isolates could delay the growth of Aspergillus fungi. They attributed this property to the high production of organic acids by this lactic isolate, such as phenyl lactic acid, 4-hydroxyphenyl lactic acid, and other antifungal protein compounds (23).

Manini et al. (2016) stated that L. brevis isolated from the sourdough of wheat bran had an effective potential to inhibit the growth of $A$. niger. This inhibitory property on the growth of the studied fungi might be due to the effect of its metabolites on the germination and growth of the fungi (24).

Coda et al. (2011) evaluated the antifungal activity of $\mathrm{LAB}$, including L. plantarum $1 A 7$ and Wickerhamomyces anomalus LCF1695 on the fungi Penicillium roqueforti $D P P M A F 1$ that can elevate the shelf life of wheat bread. Among these isolates, only $L$. plantarum $1 A 7$ could inhibit Penicillium fungi and fungal contamination was not observed in the bread produced with sourdough containing this lactic isolate for up to 7 days (25).

Yan et al. (2016) conducted research on the antifungal activity of $L$. plantarum against $P$. roqueforti under laboratory conditions as a preservative in the processing of Chinese steamed bread. These authors indicated that $L$. plantarum had an appropriate inhibitory potential on the growth and germination of Penicillium spores. According to the results of the mentioned study, acetic acid and phenyllactic acid produced by this lactic acid isolate were the most important antifungal factors of this isolate. Chinese steamed bread prepared using this lactic isolate had a suitable sensory characteristic for up to 7 days and no fungal contamination was observed in it (26).

\section{Conclusion}

Fungal spoilage of bakery products could lead to severe economic loss and health damage to any country. The loss of bakery products, on one hand, and the risks posed by the production of mycotoxins to human health, on the other hand, have prompted researchers to conduct some studies on the use of microorganisms or their metabolites for preventing fungal spoilage and improving food shelf life.

According to the results of the present study, among the four studied lactic isolates, L. brevis and L. sakei had the highest inhibitory effects of $30.25 \%$ and $18.47 \%$ against $A$. niger, respectively. Consequently, the antifungal effect of the supernatant of these species was examined. The MIC of a supernatant deterrent for L. brevis and L. sakei against $A$. niger was $3 \%$.

Considering the greater effect of the supernatant of L. brevis, the compounds of its supernatant were identified using GC/MS. We observed that it consisted of 15 compounds, including ester, phenol, and barbiturates. Therefore, it can be concluded that the predominant lactic isolates of oat bran sourdough have proper antifungal influence against $A$. niger making it suitable as a starter culture or mobile culture in the production of fermented products, such as sourdough to reduce fungal spoilage.

\section{Acknowledgment}

The authors would like to thank the esteemed experts of the Food Control Laboratory of Golestan University of Medical Sciences for their sincere cooperation in conducting this research, as well as the professors and officials of Saee Higher Education Institute of Gorgan for their assistance.

\section{Conflict of Interest}

Authors declared no conflict of interests. 


$$
\begin{aligned}
& \text { مجله ميكروبشناسى يزشكى ايران }
\end{aligned}
$$

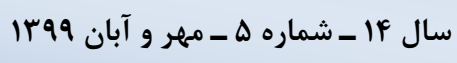

$$
\begin{aligned}
& \text { Journal homepage: www.ijmm.ir }
\end{aligned}
$$

\title{
جداسازى و شناسايى فلور باكترىهاى اسيد لاكتيك (LAB) غالب از خمير ترش سبوس جو دوسر و بررسى قابليت ضد قارجي آنها
}

\author{
طاهره معصوم شاهى'، جلال احسانى اث،، مريم ابراهيمى'
}

' . مركز تحقيقات سلامت فرآوردهاى غذايى، دارويى و طبيعى، دانشعاه علوم يزشكى كلستان، كر كان، ايران

\section{جكيله}

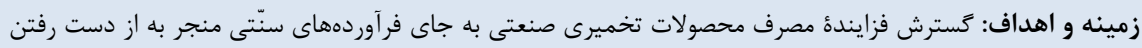

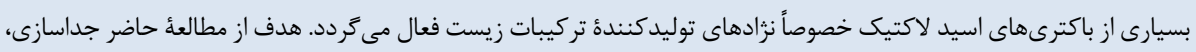

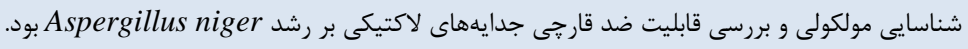

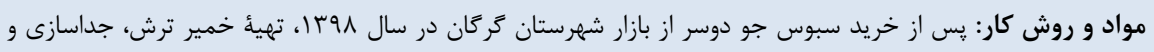

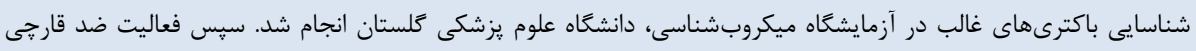

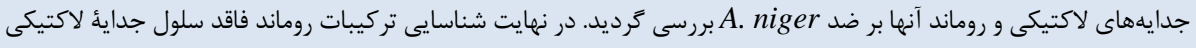

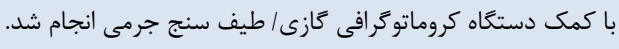

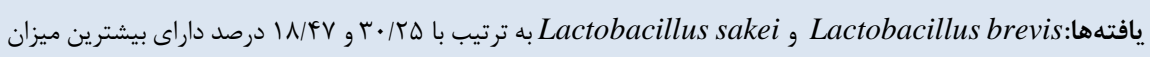

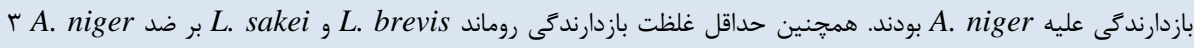

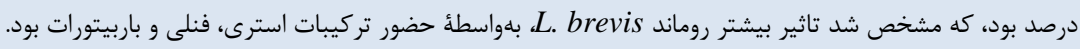

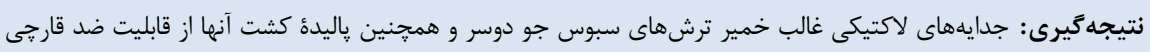

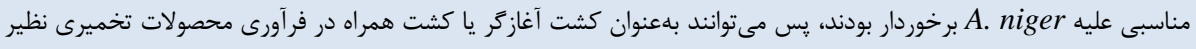
خمير ترش با هدف كاهش فساد قارجى استفاده شوند.

$$
\text { كليد وازهها: اثر ضد قارجى، باكترىهاى اسيد لاكتيك، خمير ترش. }
$$

اطلاعات مقاله تاريخهُ مقاله

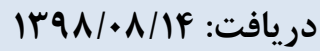

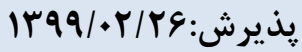
انتشار آنلاين: موضوع:ميكروبيولوزى مواد غذايى

نويسندهُ مسئول: جلال احسانى، مركز تحقيقات سلامت

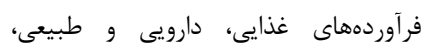
دانشخاه علوم يزشكى كلستان، كر كان، ايران ايميل: دانئ

مقدمه

اثر آنتاكونيسمى و بىضرر براى كاهش رشد كيى Aspergillus و

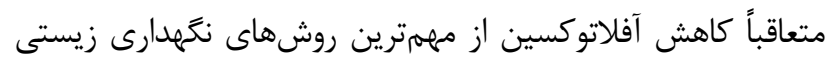

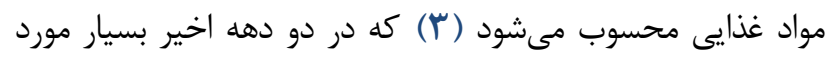

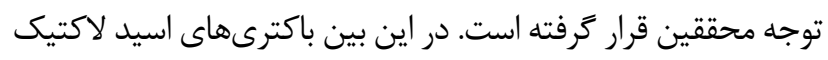
از قابليت توليد تركيبات ضد ميكروبى نظير اسيدهاى آلى، دى استيل،

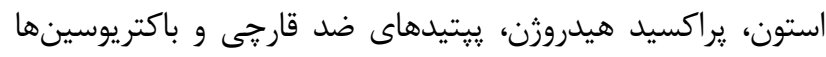

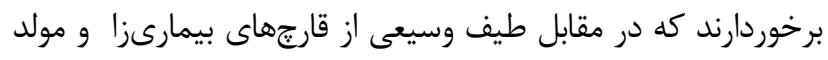

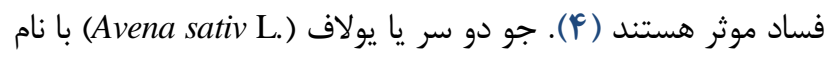

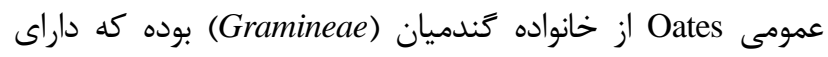
ميوههايى شبيه به جو و منتهى به دو نوك تيز است. جو دو سر از
فساد محصولات نانوايى اساساً ناشى از رشد كيكهاست. رشد

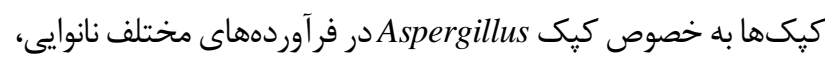

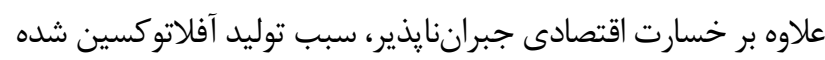

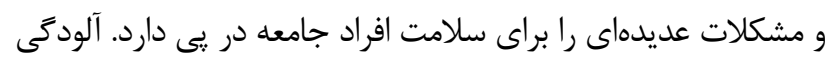

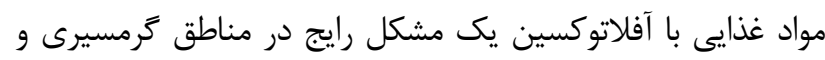

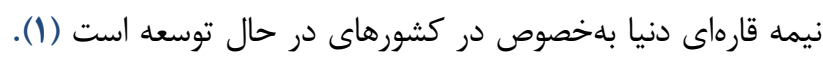

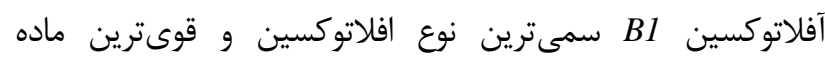

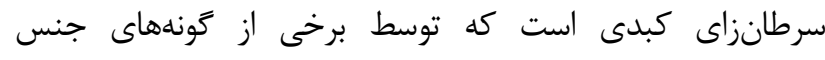

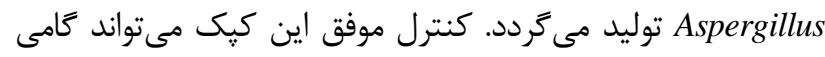

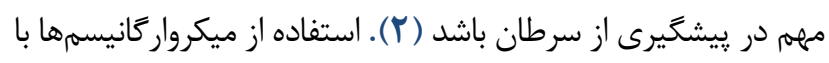


I Y يس از تهيه نسبت مناسب، خميرترش توليدى در دماى. درجه سلسيوس و به مدت MF ساعت تخمير شد. سيس در هر

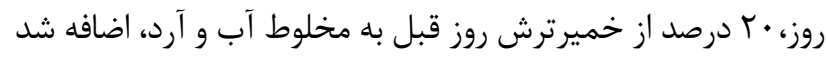
(مايه

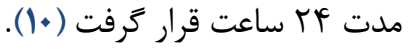

\section{جداسازى و شناساييى اوليه باكترىهاى اسيد لاكتيك}

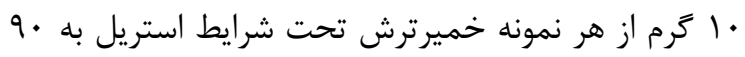

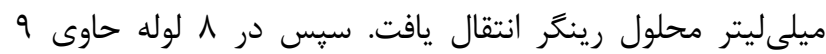

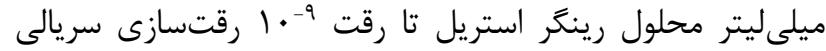

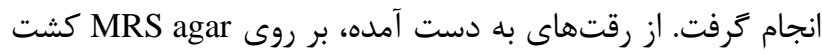

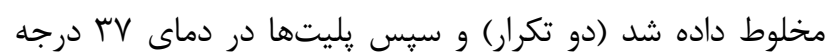

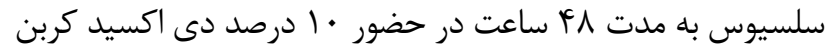

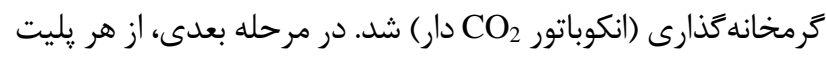
براساس تفاوت در ويزگى هاى مورفولوزيكى ير گنهها (رنت، شكل، تحدب و تعقر، عمقى يا سطحى بودن) جند پيرگنه انتخاب و براى

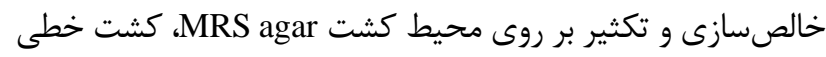
داده شد. يس از جداسازى، شناسايى اوليه جدايههاى لاكتيكى با

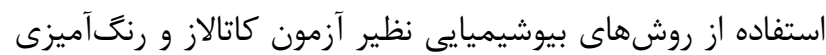

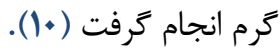

\section{شناسايى باكترىهاى اسيد لاكتيك با انجام واكنش}

زنجيرهاى يليمراز (Polymerase Chain Reaction)

يس از جداسازى و شناسايى اوليه جدايههاى لاكتيكى با استفاده از روشهاى بيوشيميايى و مورفولوزيكى شامل آزمونهاى كاتالاز و رنتَآميزى گرم، شناسايى باكترىهاى اسيد لاكتيك با استفاده از PCR داراى يرايمر اختصاصى انجام گرفت (1). در اين مرحله، استخراج DNA توسط كيت تجارى GeneAll (كره جنوبى) يمري) طبق دستورالعمل شركت سازنده انجام شد. همجنين :يرايمر مورد استفاده و شرايط واكنش PCR مطابق روش Yang و همكاران

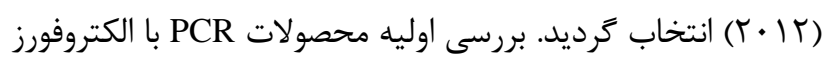

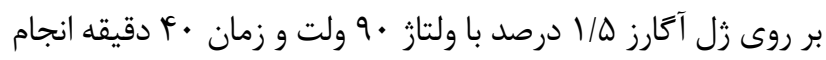
شد. يس از الكتروفورز و تاييد اوليه، محصولات PCR جهت توالى ريابى به شركت بيونير كره جنوبى ارسال گرديد. سيس بلهمنظور شناسايى

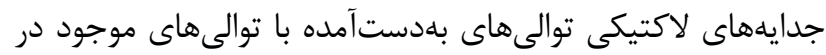
"National Center Bitechnology Information) بايخاه اطلاعاتى NCBI جنس و گونه شناسايى شد (1).
علفهاى خودرو بوده و به علت سازگارى با انواع آب و هوا در نقاط مختلفى از دنيا و حتى ايران كشت مى گردد ( و ،ه). خمير ترش اين دانه غلهاى مىتواند بهعنوان يكى از منابع مهرم جهت جداسازى باكترىهاى اسيد لاكتيك مطرح باشد. در ارتباط با جداسازى و

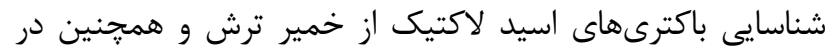
ارتباط با بررسى ضد قارجى اين جدايهها يثوهشهاى متعددى به به

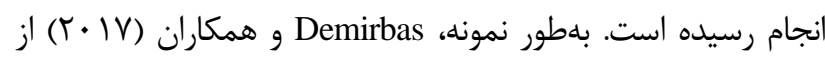
يك نمونه خميرترش سنتى، ها باكترى اسيد لاكتيك را جداسازى و

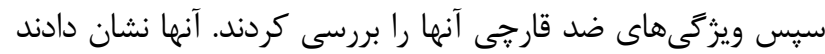
كه Lactobacillus , Lactobacillus paraplantarum Penicillium بالاترين قابليت ضد قارجى عليه paralimentarius 1, Aspergillus niger g chrysogenum Sadeghi قارجى Pediococcus pentosaceus جدا شده از خميرترش آرد جو و روماندهاى حاصل از كشت اين جدايه لاكتيكى بر عليه Aspergillus نشان داد كه جدايه لاكتيكى P. pentosaceus و همجنين روماندهاى حاصل از كشت آن داراى خاصيت ضد قارجى بودند (1). همواره استفاده از روشهاى نوين شناسايى و تعيين ويزگگىهاى كاربردى باكترىهاى اسيد لاكتيك در زيستبومهايى كه كمتر مورد مطالعه قرار گرفتهاند امكان دستيابى به جدايههايى با قابليتهاى منحصر به فرد را افزايش داده است. فرآوردههاى غذايى تخميرى نظير سبوسهاى تخمير شده، زيستخاه بسيار مناسبى براى باكترىهاى

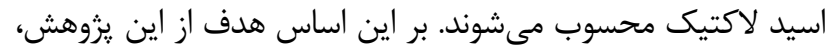
جداسازى، شناسايى مولكولى و بررسى تاثير جدايههاى لاكتيكى غالب موجود در خميرترش سبوس جو دو سر و قابليت ضد قارجى آنها بر رشد A. niger است.

\section{روش يثروهش}

اين مطالعه تجربى در سال ^هץ| در آزمايشعاه ميكروبشناسى، معاونت غذا و دارو دانشعاه علوم يزشكى كلستان انجام شد. در اين يزوهش يس از تهيئ آرد سبوس جو دو سر از سطح

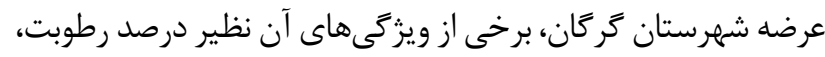
يروتئين و خاكستر براساس روشهاى مدون تعيين گرديد (9) و در مرحله بعد خمير ترش آن تهيه شد.

\section{تهييه خميرترش}

براى تهيئ خميرترش از آرد سبوس جو دوسر، براساس ميزان

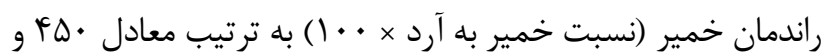


شناسايى تركيبات روماند فاقد سلول جدايه لاكتيكى با

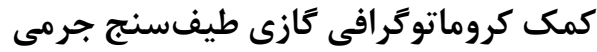

ابتدا روماند بلهدتآمده از جدايه لاكتيكى (با بيشترين

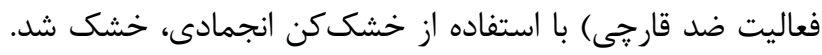

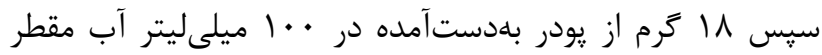

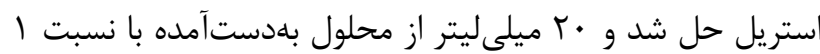

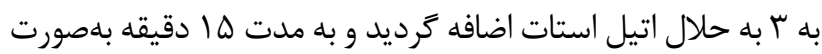
مداوم و با دست تكان داده شد. طى اين عمل كليه تركيبات آلى به آله فاز اتيل استات منتقل كرديد و اين فاز در سطح فاز آبى قرار كرفت

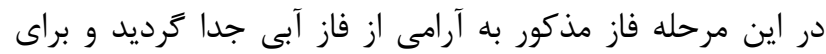

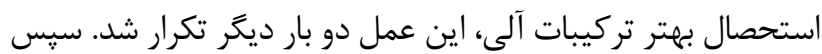

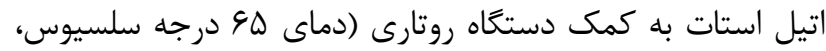

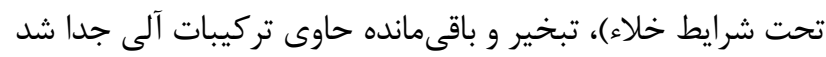

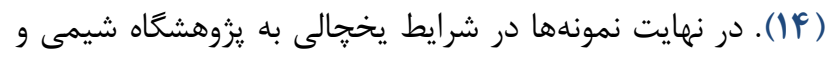
مهندسى شيمى ايران براى شناسايى تركيبات آلى، ارسال گرديد. مشخصات دستكاه كروماتوكرافى كازى - طيفسنج جرمى مورد استفاده در اين تحقيق عبارت است از: إن إن

- شركت و كشور سازنده: Agilent، مدل 7890B، آمريكا - عاز حامل (فاز متحرك): كاز هليوم با جريان ا ميلىليتر در دقيقه - ستون (فاز ثابت): Agilent Hp5Ms با طول •r متر، قطر

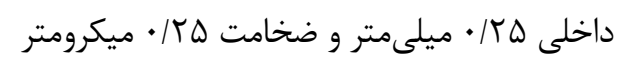

$$
\text { آناليز آمارى }
$$

تمام آزمونها با سه تكرار و در قالب طرح كاملاً تصادفى اجرا

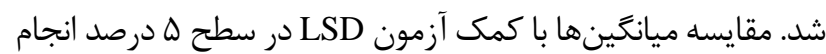

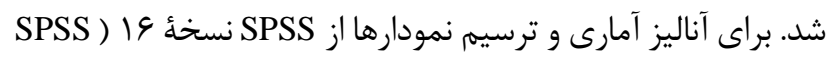
(Inc., Chicago, Ill., USA

يافته ها

\section{ويثزىى هاى مواد خام و تغييرات pH و اسيديته قابل تيتر}

\section{در طول دوره تخمير خميرترش سبوس جو دوسر}

نتايج حاصل از آزمونهاى شيميايى آرد سبوس جو دوسر شامل

درصد رطوبت، يروتئين و خاكستر در جدول آل آورده شده است.

همجنين روند تغييرات اسيديتهٔ قابل تيتر خميرترش

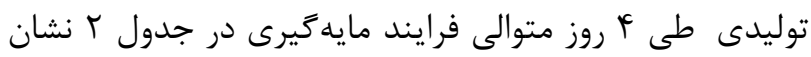
داده شده است. همان طور كه مشاهده مى كردد با افزايش زمان دمان
بررسى فعاليت ضد قارجى جدايههاى لاكتيكى

براى بررسى فعاليت ضد قارجى جدايه هاى لاكتيكى، از

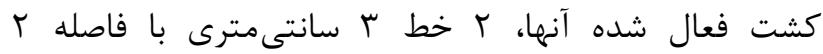
سانتى متر از هم بر روى محيط كشت MRS agar كشيده شد.

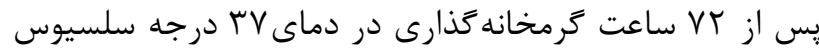

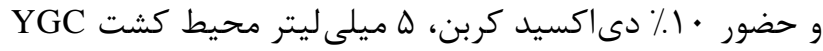

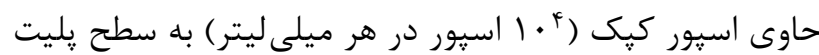
اضافه و در دماى rV درجه سلسيوس در شرايط هوازى كرمخانه كذارى شد. سيس قطر رشد كلنى كيى بـ به صورت

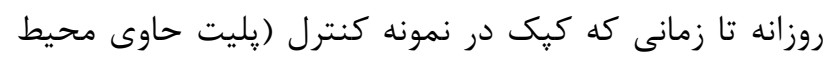
كشت MRS agar با لايهاى از محيط كشت YGC حاوى اسيور

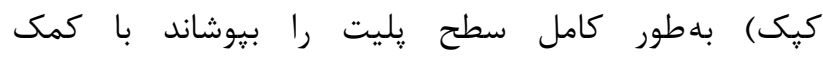

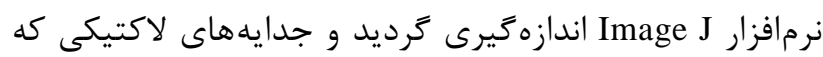

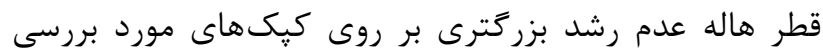
ايجاد كردند، انتخاب شد (r) (I).

\section{تمهيه روماند فاقد سلول}

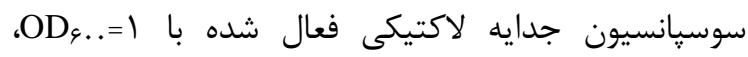

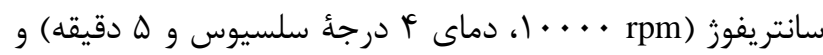
در نتيجه روماند فاقد سلول جدا كرديد. در ادامه با اضافه كردن

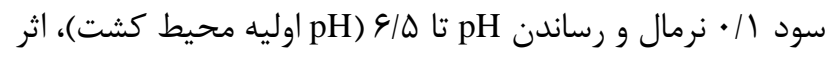

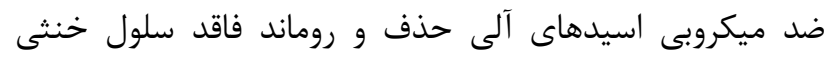

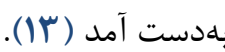

\section{بررسى فعاليت ضد قارجى روماند جدايههاى لاكتيكى}

براى تعيين اثر ضد كيكى، 1 تا • ا درصد از روماند فاقد

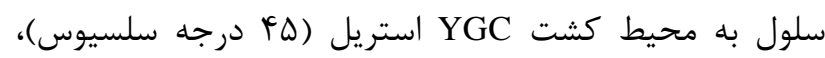
اضافه و در يليت ريخته شد. نمونه كنترل، شامل محيط كشت YGC

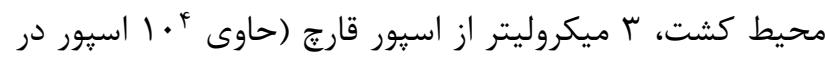

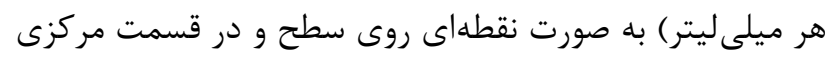

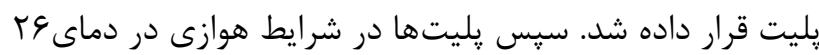

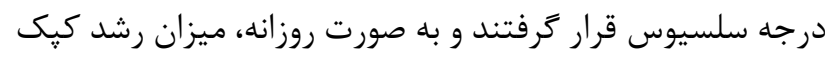
أنا زمانى كه كيك در نمونه كنترل بهطور كامل سطح يليت بيوشاند اندازهگيرى گرديد. جدايه لاكتيكى كه داراى بإيينترين

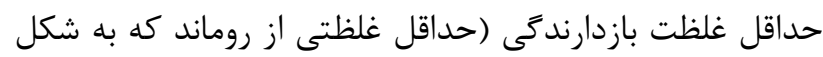

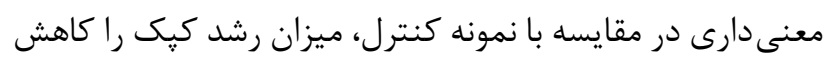
دهد) بر روى كيكهاى مورد بررسى باشد براى ادامه مطالعه

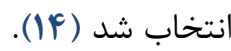




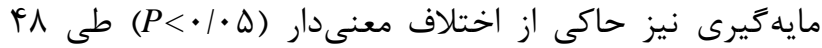

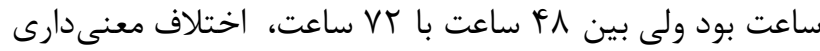

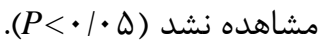

تخمير، ميزان pH كاهش و ميزان اسيديته قابل تيتر خميرترش سبوس جو دوسر افزايش يافته است. همجنين مقايسٔ مقادير

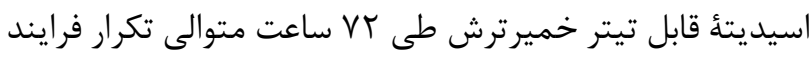

\begin{tabular}{|c|c|c|}
\hline بروتئين & خاكستر & رطوبت \\
\hline $\mid r / 9 \wedge \pm \cdot \cdot / \cdot 1$ & $T / V F \pm \cdot / \cdot 1$ & $1 \cdot / F_{F} \cdot \pm / \cdot F$ \\
\hline
\end{tabular}

\section{جدول r. تغييرات pH و اسيديته قابل تيتر در طول تخمير خميرترش سبوس جودوسر}

\begin{tabular}{|c|c|c|}
\hline اسيديته قابل تيتر (دورنيك) & pH & زمان \\
\hline $\mathrm{a} \cdot / r \Delta \pm \mid \varepsilon / F \Delta$ & a. $/ \cdot \Delta \pm \varepsilon / \& r$ & - \\
\hline $\mathrm{b}_{1 / 1 \Delta \pm r \cdot / 99}$ & $a \cdot \mid \cdot r \pm \varepsilon / \cdot r$ & rF \\
\hline$c \cdot / f \pm r \mid / f \Delta$ & b. $\cdot 1 \cdot \Delta \pm r / q r$ & $i \wedge$ \\
\hline$c^{c} 1 / r \Delta \pm r m / r \Delta$ & $c \cdot 1 \cdot 9 \pm F / \Delta \Lambda$ & Vr \\
\hline
\end{tabular}

است. نتايج توالى يابى محصولات PCR يس از مقايسه همرديفى با توالى هاى موجود در بانك جهانى زن منجر به شناسايى جدايه

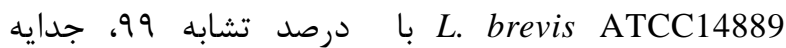
Lactobacillus sakei NBRC 15893 Enterococcus hirae ATCC9790 با درصد تشابه 9V و جدايه P. pentosaceus ATCC 20336 به عنوان جدايه هاى لاكتيكى خميرترش سبوس جو دو سر شد.

\section{جداسازى و شناسايى جدايه هاى لاكتيكى}

به منظور شناسايى جدايه هاى لاكتيكى غالب يس از س روز تكرار فرايند مايه گيرى خميرترش، باكترىهاى اسيد لاكتيك لهن هر خمير ترش به روشى كه توضيح داده شد جدا گرديدند. نتايج

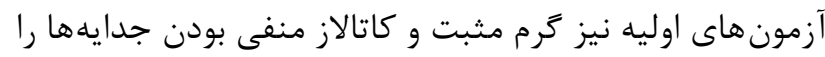
تاييد نمود. همجنين با توجه به شكل ا، زل زل الكتروفورز

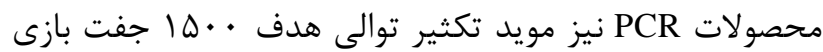

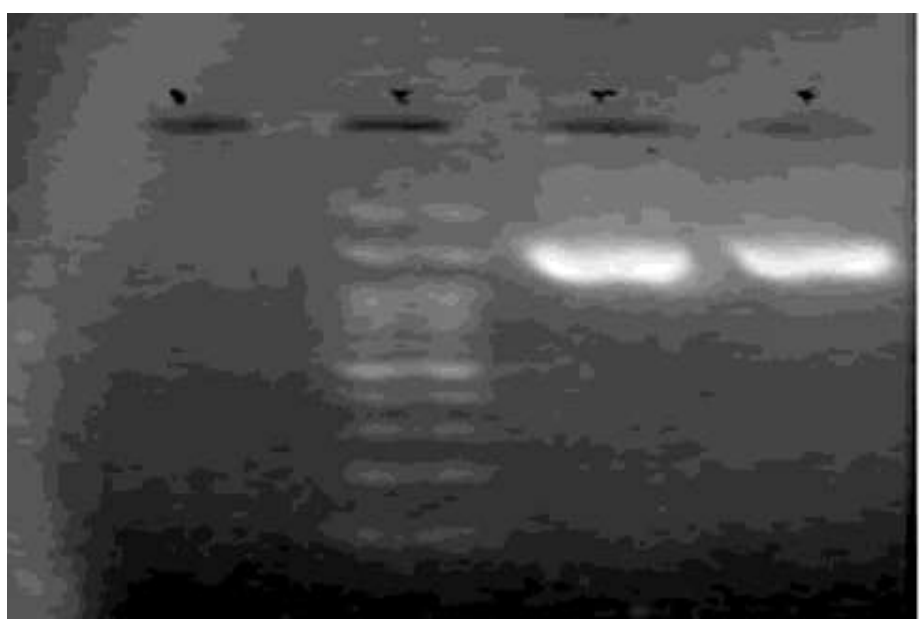

شكل ا. زل الكتروفورز محصولات PCR داراى يرايمر اختصاصى با توالى هدف . •Dا جفت بازى جهت شناسايى جدايه لاكتيكى (لاين) در مجاورت ماركر صد جفت

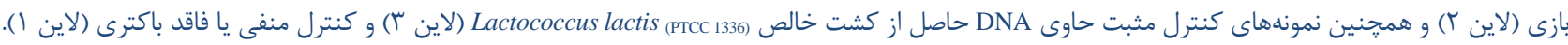


مىشود A. niger، در پايان روز جهارم، تمام سطح يليت كنترل را

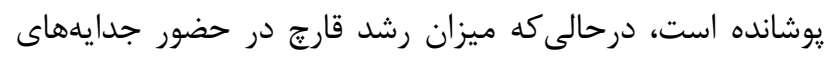

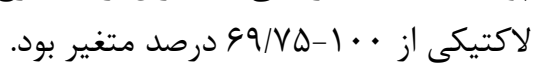

\section{ارزيابى تاثير جدايههاى لاكتيكى بر رشد A. niger} فعاليت ضد قارجى جدايههاى لاكتيكى بر ضد A. niger در جدول شماره r نشان داده شده است. همانطور كه مشاهده

\section{جدول ץ. درصد رشد Aiger در حضور جدايه هاى لاكتيكى در طول عا روز كرمخانه كذارى}

\begin{tabular}{|c|c|c|c|c|}
\hline \multicolumn{4}{|c|}{ روز } & \multirow{2}{*}{ كد } \\
\hline f & $r$ & r & 1 & \\
\hline $1 \cdot \cdot^{*}$ Aa & $9 \Delta / r T \pm Y / /)^{A b}$ & $\Delta \xi / \cdot \Delta \pm \Delta / \Lambda G^{A c}$ & $1 \cdot\left|\Delta \Phi_{ \pm}\right| / F Y^{\mathrm{Ad}}$ & Control \\
\hline Са $/ \cdot \vee \pm 99 / V \Delta$ & Eb $r / \Lambda \pm r \cdot / r \Delta$ & $\mathrm{Cc} \pm \cdot / \cdot$ & $\mathrm{Bc}^{\mathrm{Bc}} \pm \cdot$ & L. brevis \\
\hline Bay $/ / r \pm \Lambda / / \Delta r$ & Db $/ / \Delta q \pm \Psi V / r$ & $\operatorname{Dc}^{\prime} / \mathcal{F} \mid \pm V / l$ & Bd \pm • & L. sakei \\
\hline${ }^{\text {Aa }} \cdot \pm 1 \cdot \cdot$ & 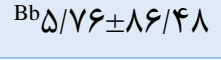 & ${ }^{A c} \Delta / \cdot r \pm \Delta I / \cdot r$ & $\mathrm{Bd}^{\mathrm{B}} \pm$ & E. hirae \\
\hline${ }^{\mathrm{Aa}} \cdot \pm 1 \cdots$ & $\mathrm{Cb} / / q) \pm V \Delta / \mathcal{F}$ & Bc $r / r \Delta \pm r q / \mathcal{F} \Delta$ & ${ }^{\mathrm{Bd}} \cdot \pm \cdot$ & P.pentosaceous \\
\hline
\end{tabular}

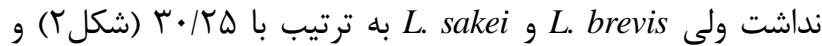

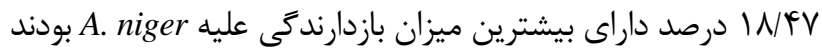

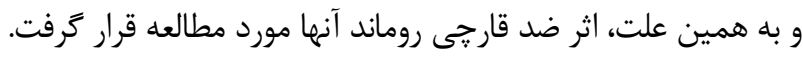

نتايج نمايش داده شده در جدول "ا، مبين اين موضوع است كه

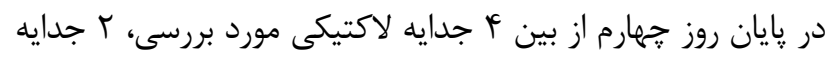
تاثير معنى دارى در كاهش رشد A. niger در مقايسه با يليت كنترل

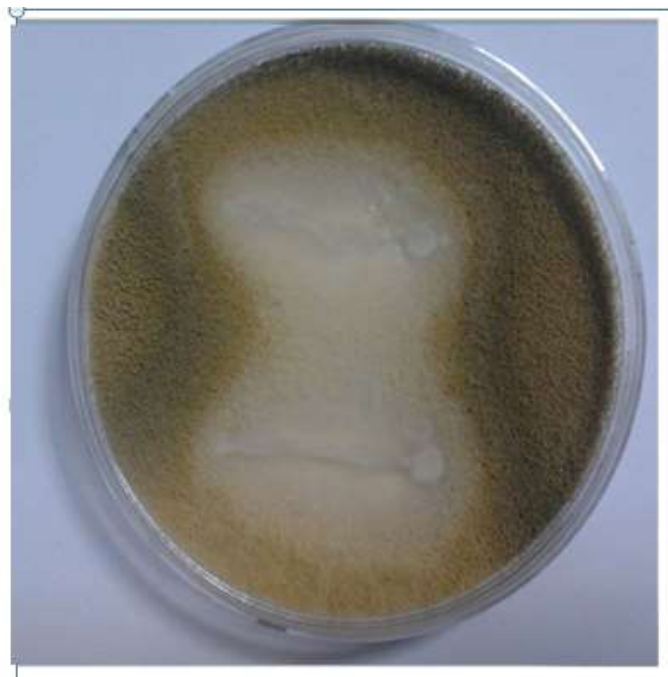

A

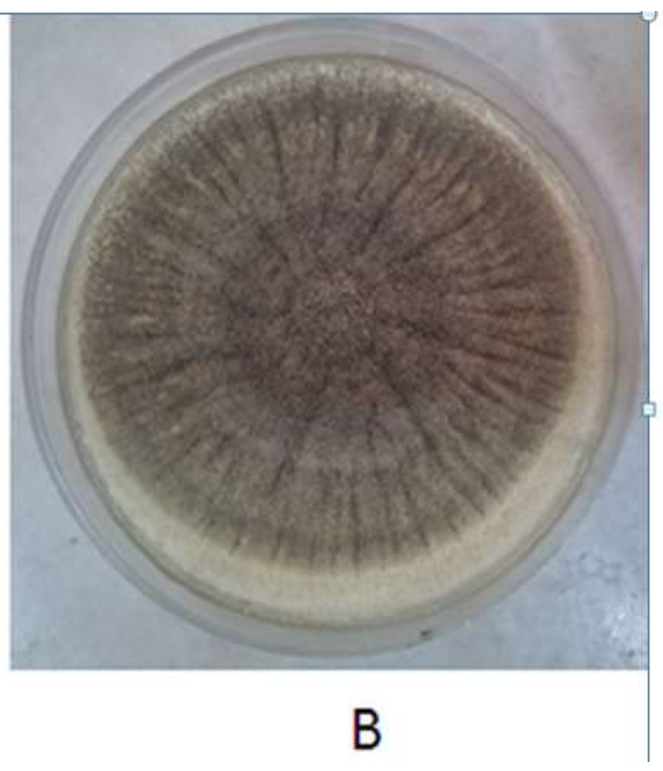

B

شكل r. تاثير ضد قارجى A. brevis (شكل A) بر عليه A. niger و مقايسه آن با نمونه كنترل (شكل B)

r riger به L. sakei در هر سه سطح روماند بيشتر بود.
طبق نتايج حاصل از جدول شماره F و شكل شماره r حداقل

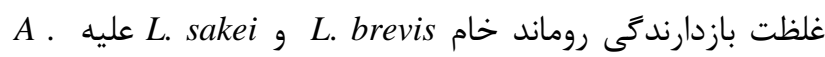




\section{جدول F. درصد رشد A. niger در حضور روماند خام جدايههاى لاكتيكى}

\begin{tabular}{|c|c|c|}
\hline L. sakei & L. brevis & روماند خام (درصد) \\
\hline $1 \cdots \pm \cdot$ Aa & $1 \cdots \pm \cdot$ Aа & • (كنترل) \\
\hline $1 \cdots \pm \cdot$ Aa & $1 \cdots \pm \cdot$ Aa & 1 \\
\hline $1 \cdots \pm \cdot$ Aa & $1 \cdots \pm \cdot$ Aa & r \\
\hline$q \vee / 9 \Delta \pm r / \cdot \Delta^{\mathrm{Aa}}$ & $9 \varphi / r r \pm \Lambda / \vee \Lambda^{B b}$ & r \\
\hline$q r / \backslash \Lambda \pm r / 1 q^{\mathrm{Ab}}$ & $\kappa V / q r \pm \Delta / r \omega^{\mathrm{Bc}}$ & r \\
\hline$\Lambda 9 / V \Gamma \pm r / \Delta \Delta^{A c}$ & $\mu F / / f \pm \Lambda / q \omega^{\mathrm{Bc}}$ & $\Delta$ \\
\hline
\end{tabular}

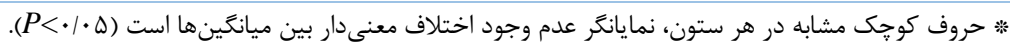
* حروف بزرى مشابه در هر رديف نمايانكر عدم وجود اختلاف معنىدار بين ميانكَينها است (ه./•>P).

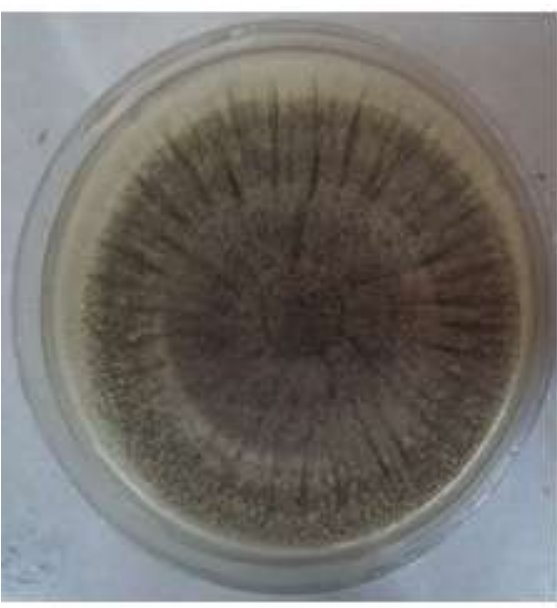

A

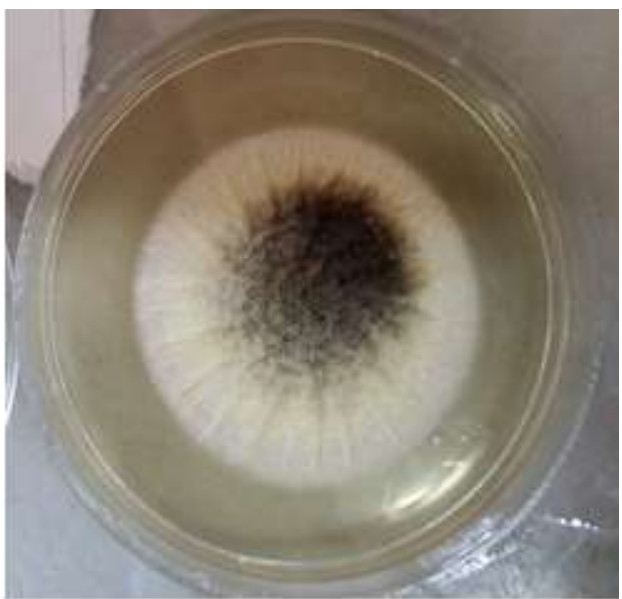

B

شكل س. رشد A. niger در حضور r درصد از روماند L. brevis (شكل B) در مقايسه با نمونه كنترل (شكل A)

قرار گرفت. با استفاده از شباهت طيف جرمى و كتابخانه جرمى

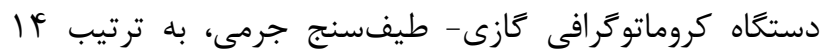
تركيب در روماند خام كه شامل اسيدهاى جرب، استر، فنل، باربيتوراتها بود شناسايى گرديد (جدول ه).

\section{جداسازى و ارزيابى تركيبات آلى روماند خام}

L. با توجه به نتايج قسمت قبل و تاثير بيشتر روماند خام brevis كروماتو

$$
\text { جدول ه. تركيبات آلى شناسايى شده در روماند خام }
$$

\begin{tabular}{|c|c|c|c|}
\hline زمان بازدارى & 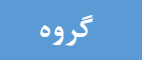 & 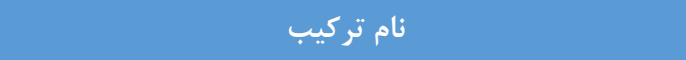 & رديف \\
\hline $\mid r / 991$ & 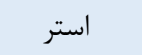 & Lactic acid, 3-phenyl-methyl ester & 1 \\
\hline Ir/ANK & اسيد حرب & $n$-Decanoic acid & r \\
\hline$|Q / r T|$ & استر & Benzenepropanoic acid, a-hydroxy-methyl ester & r \\
\hline $19 / V \Delta F$ & اسيد خرب & Acetic acid & r \\
\hline
\end{tabular}




\begin{tabular}{|c|c|c|c|}
\hline زمان بازدارى & 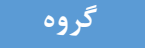 & نام تركيب & 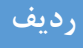 \\
\hline$r \cdot / t \cdot r$ & 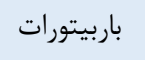 & 5-Ethyl-5-isopropylpyrimidine-2,4,6(1H,3H,5H)-trione & $\Delta$ \\
\hline$r \cdot / \uparrow \Delta \Lambda$ & 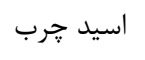 & Pentadecanoic acid & 4 \\
\hline$r \cdot / 914$ & 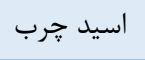 & Palmitic acid & v \\
\hline TT/TVT & اسيد جرب & 1-Mono-linolein & $\wedge$ \\
\hline Tr/GDT & اسيد جرب & 9-Hexadecenoic acid & 9 \\
\hline TF/MFT & 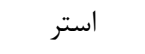 & Decanedioic acid dibutyl ester & $1 \cdot$ \\
\hline TF/DFF & استر & Hexanedioic acid mono(2-ethylhexyl) ester & 11 \\
\hline$Y Y / V \wedge \Lambda$ & استر & Octadecanoic acid 9,10-dihydroxy-methyl ester & ir \\
\hline$r \Delta / 1 \cdot 9$ & 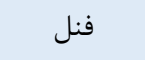 & N-Formyl-D-phenylalanine & r \\
\hline re/ANT & 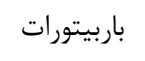 & 5-Ethenyl-5-pentan-2-yl-1,3-diazinane-2,4,6-trione (vinilbital) & if \\
\hline
\end{tabular}

Lر اين تحقيق جهار نوع باكترى اسيد لاكتيك به نام هاى جاز

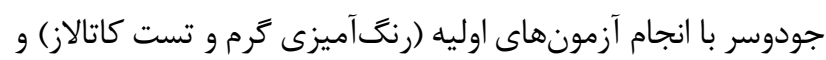

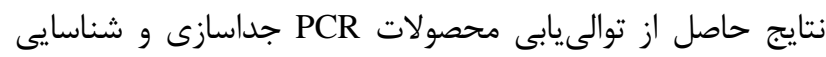
كرديد. مشابه تحقيق حاضر، Gobbetti و همكاران (991 (191) توانستند

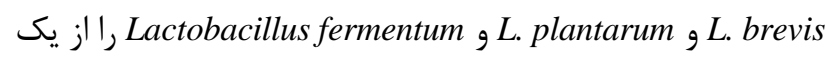
نمونه خمير ترش آرد كندم بلعنوان جدايههاى غالب جدا كنند

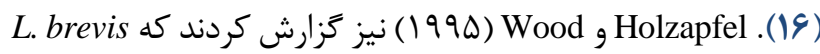

و باكترىهاى غالب در خميرترش هستند (IV. fermentum (ن).

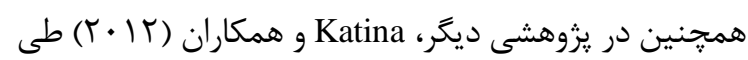

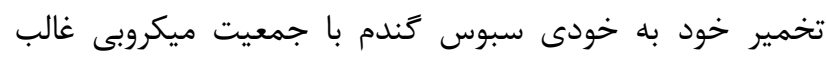

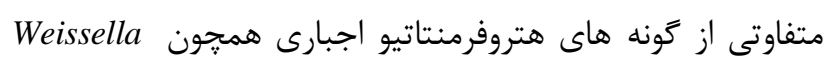
Weissella confuse cibaria

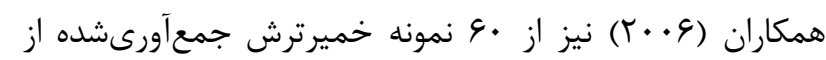

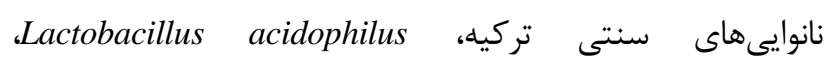
،L. brevis ،Lactobacillus viridescens ،L.plantarum و , L. sakei Lactobacillus delbrueckii Robert را جداسازى كردند (19) Pediococcus و Lactobacillus

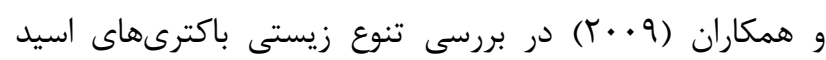

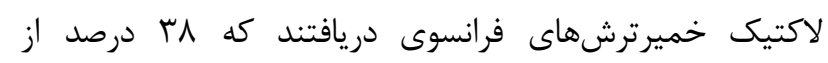
باكترىهاى اسيد لاكتيك جداشده به جنس

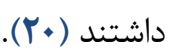

\section{بحث}

در حالى كه كشورهاى بيشرفته حدود يك قرن است كه بلهور جدى به كشف و شناسايى كونههاى جديد باكترىهاى اسيد اسيد

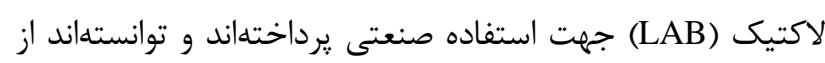
اين باكترىها بهطور وسيعى در صنعت بهره ببرند، در كشور ما تنها

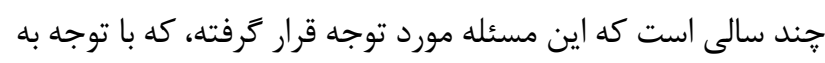

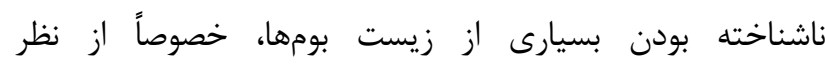

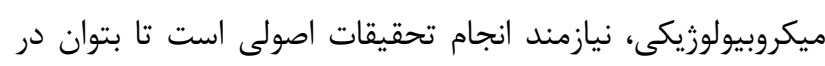

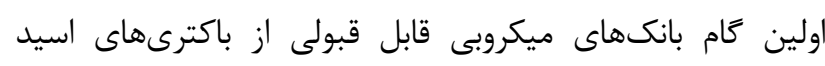

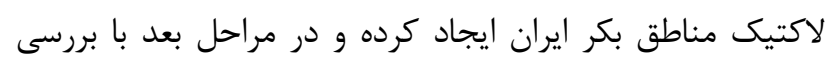

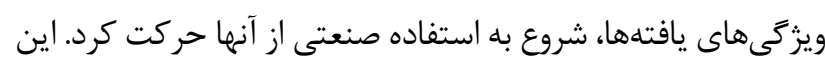

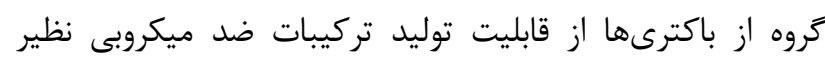

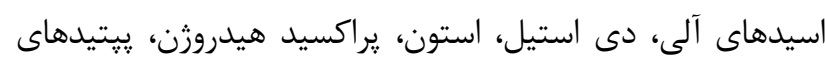

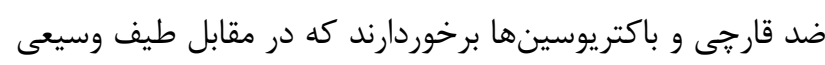

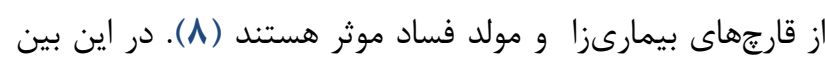

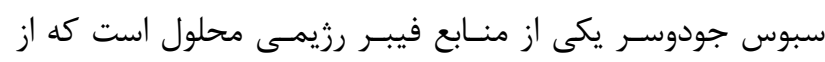

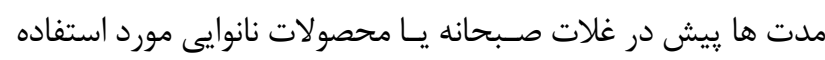

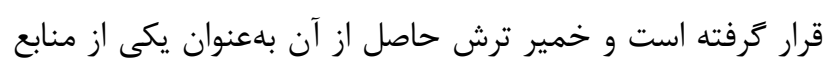

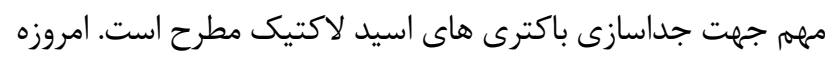

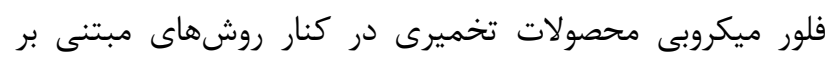

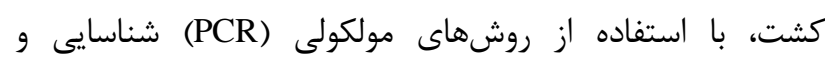
طبقهبندى مىشوند (ه) (1). 
عوامل موثر بر فعاليت ضد قارجى اين جدايه لاكتيكى بودند. نان بخاريز

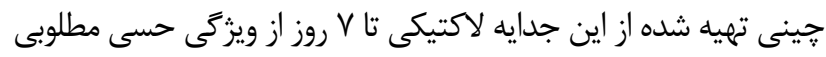

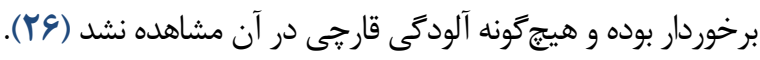

$$
\text { نتيجهليرى }
$$

فساد قارجى محصولات نانوايى منجر به ايجاد خسارات

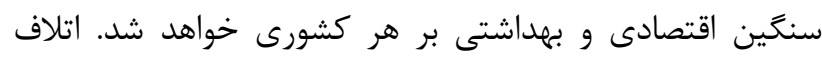
محصولات نانوايى از يك سو و مخاطرات ناشى از تونى نوليد مايكوتوكسينها بر سلامت انسان از سوى ديخر باعث شده كه آنه

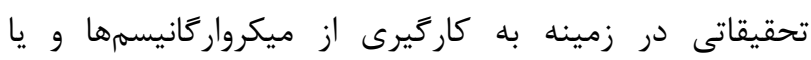

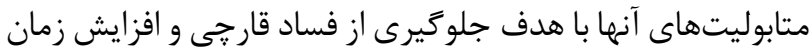

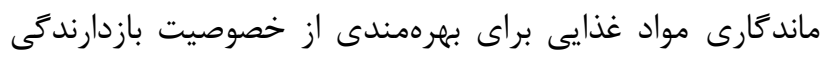

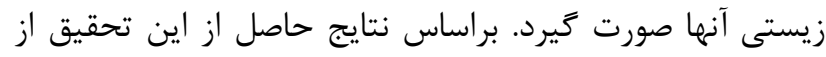

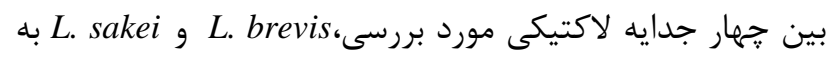

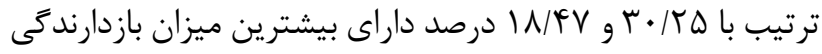

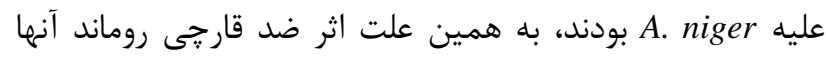

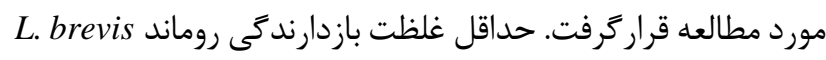

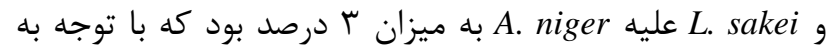

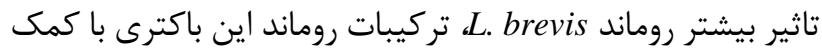

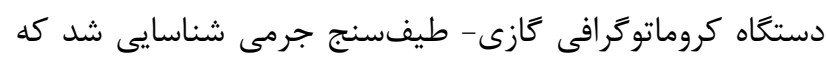
شامل ها تركيب استرى، فنلى و باربيتورات بود. بر اين اساس كاس

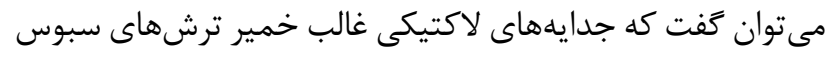

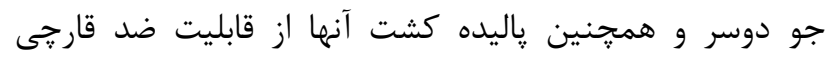

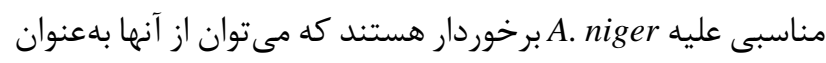

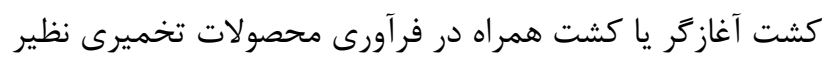
خمير ترش با هدف كاهش فسادهاى قارجى استفاده نمود. سياسگزارى نويسندكان از كارشناسان محترم آزمايشكاه كنترل مواد

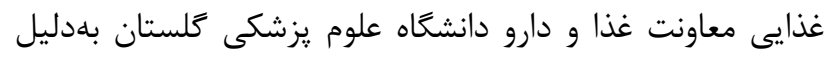
همكارى صميمانه در انجام اين تحقيق و همجنين از اساتيد و

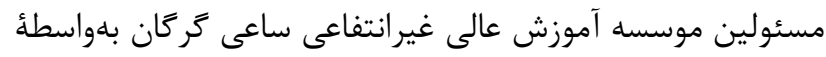
مساعدت هايشان تشكر و قدردانى مىنمايند.

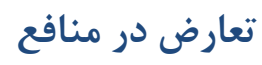

اين مقاله يزوهشى مستقل است كه بدون حمايت مالى

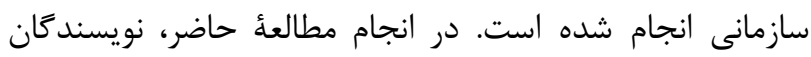
هيج كونه تضاد منافعى نداشتهاند.
در ارتباط با فعاليت ضد قارجى جدايه لاكتيكى بهدستآمده

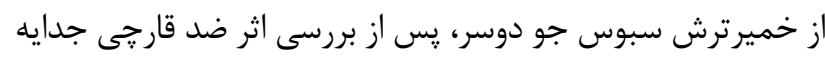

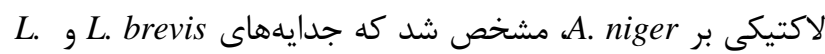
قابليت مهار كنندكى بيشترى دارند. خاصيت بازدارندكى اين sakei

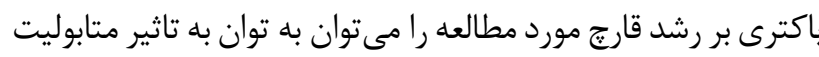

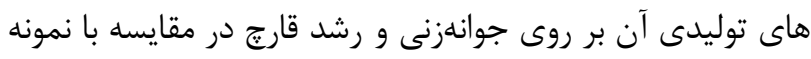

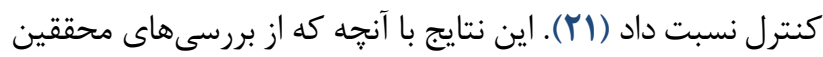

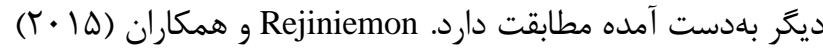

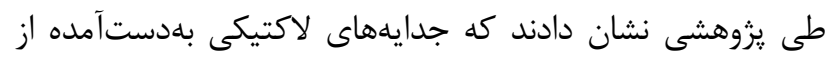

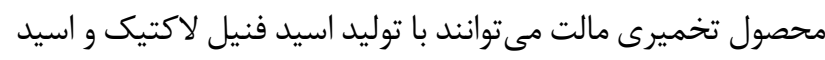
F-هيدروكسى فنيل لاكتيك به طور قابل ملاحظهاى رشد

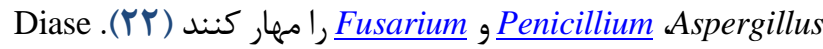

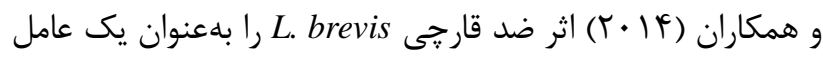

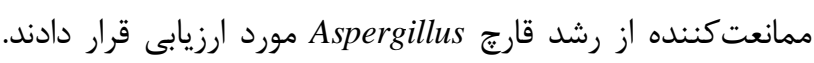
نتايج اين يروهش حاكى از آن بود كه جدايه لاكتيكى مذكور مى تواند

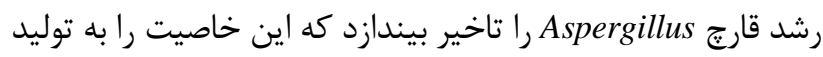

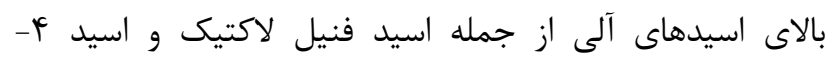
هيدروكسى فنيل لاكتيك و ساير تركيبات يروتئينى ضد قارجى الإيد

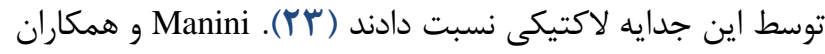

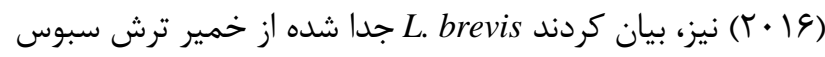
كندم، به نحو موثرى داراى قابليت مهاركنند

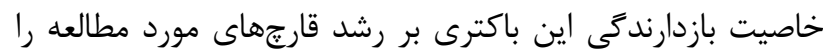

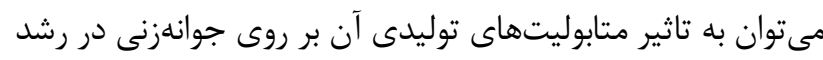

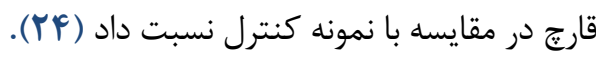

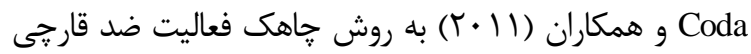
Lاكترىهاى اسيد لاكتيك شامل

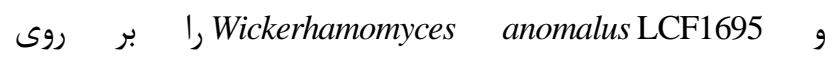
قارج Penicillium roqueforti براى افزايش زمان ماندًارى نان كندم

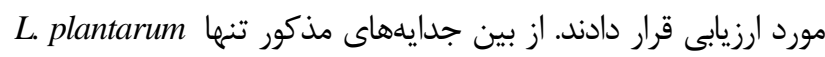

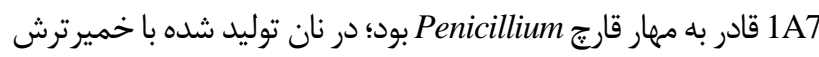

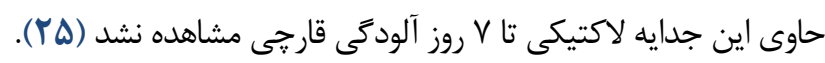
نتايج تحقيقات Yan و همكاران (9 • (Y) بر روى فعاليت ضد قارجى

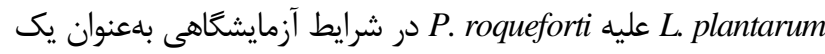

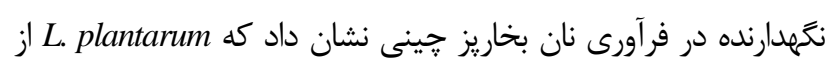
Penicillium قابليت مهاركنند

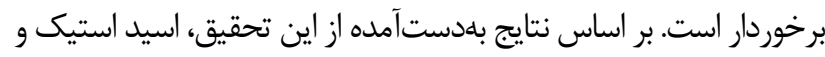
اسيد فنيل لاكتيك توليد شده توسط جدايه لاكتيكى مذكور مهمترين 
1. Gupta RC. Chapter 55 - Aflatoxins, ochratoxins and citrinin. In: Gupta RC, editor. Reproductive and Developmental Toxicology. San Diego: Academic Press; 2011. p. 753-63. [DOI:10.1016/B978-0-12382032-7.10055-4]

2. Wild CP, Montesano R. A model of interaction: aflatoxins and hepatitis viruses in liver cancer aetiology and prevention. Cancer Lett. 2009;286(1):22-8. [DOI:10.1016/j.canlet.2009.02.053] [PMID]

3. Silva JFM da, Peluzio JM, Prado G, Madeira JEGC, Silva MO, de Morais PB, et al. Use of probiotics to control aflatoxin production in peanut grains. Sci World J. 2015;2015:1-8. [DOI:10.1155/2015/959138] [PMID] [PMCID]

4. Gálvez A, Abriouel H, López RL, Omar N Ben. Bacteriocin-based strategies for food biopreservation. Int J Food Microbiol. 2007;120(1-2):51-70. [DOI:10.1016/j.ijfoodmicro.2007.06.001] [PMID]

5. Zargari A. Medicinal Plants. 7th ed. Tehran university; 2011. 870 p.

6. Salehi sormaghi MH. Medicinal Plants and Phytotherapy. 3rd ed. Donyaye Taghzieh; 2010. 440 p.

7. Demirbaş F, İspirli H, Kurnaz AA, Yilmaz MT, Dertli E. Antimicrobial and functional properties of lactic acid bacteria isolated from sourdoughs. LWT-Food Sci Technol. 2017;79:361-6. [DOI:10.1016/j.lwt.2017.01.067]

8. Sadeghi A, Raeisi M, Ebrahimi M, Sadeghi B. Antifungal activity of Pediococcus pentosaceus isolated from whole barley sourdough. J food Qual hazards Control. 2016;3(1):30-6.

9. AOAC. In official methods of analysis. Association of official analytical chemists. 17th ed. 2010.

10. Jones RJ, Hussein HM, Zagorec M, Brightwell G, Tagg JR. Isolation of lactic acid bacteria with inhibitory activity against pathogens and spoilage organisms associated with fresh meat. Food Microbiol. 2008;25(2):228-34. [DOI:10.1016/j.fm.2007.11.001] [PMID]

11. Yang E, Fan L, Jiang Y, Doucette C, Fillmore S. Antimicrobial activity of bacteriocin-producing lactic acid bacteria isolated from cheeses and yogurts. Amb Express. 2012;2(1):48. [DOI:10.1186/2191-0855-2-48] [PMID] [PMCID]

12. Magnusson J, Schnürer J. Lactobacillus coryniformis subsp. coryniformis strain $\mathrm{Si} 3$ produces a broadspectrum proteinaceous antifungal compound. Appl Environ Microbiol. 2001;67(1):1-5. [DOI:10.1128/AEM.67.1.1-5.2001] [PMID] [PMCID]
13. Ammor S, Tauveron G, Dufour E, Chevallier I. Antibacterial activity of lactic acid bacteria against spoilage and pathogenic bacteria isolated from the same meat small-scale facility: 1-Screening and characterization of the antibacterial compounds. Food Control. 2006;17(6):454-61. [DOI:10.1016/i.foodcont.2005.02.006]

14. Wang H, Yan Y, Wang J, Zhang H, Qi W. Production and characterization of antifungal compounds produced by Lactobacillus plantarum IMAU10014. PLoS One. 2012;7(1):e29452.

[DOI:10.1371/journal.pone.0029452] [PMCID]

15. Gürbüz I, Akyüz Ç, Yeşilada E, Şener B. Antiulcerogenic effect of Momordica charantia L. fruits on various ulcer models in rats. $\mathbf{J}$ Ethnopharmacol. 2000;71(1-2):77-82. 8741(99)00178-6]

[DOI:10.1016/S0378-

16. Gobbetti M. The sourdough microflora: interactions of lactic acid bacteria and yeasts. Trends Food Sci Technol. 1998;9(7):267-74. 2244(98)00053-3]

17. Holzapfel WH, Wood BJB. Lactic acid bacteria in contemporary perspective. In: The genera of lactic acid bacteria. Springer; 1995. p. 1-6. [DOI:10.1007/978-14615-5817-0_1]

18. Katina K, Juvonen R, Laitila A, Flander L, Nordlund E, Kariluoto $\mathrm{S}$, et al. Fermented wheat bran as a functional ingredient in baking. Cereal Chem. 2012;89(2):126-34. [DOI:10.1094/CCHEM-08-11-0106]

19. Şimşek Ö, Çon AH, Tulumog`lu Ş. Isolating lactic starter cultures with antimicrobial activity for sourdough processes. Food Control. 2006;17(4):263-70. [DOI:10.1016/j.foodcont.2004.10.011]

20. Robert H, Gabriel V, Fontagné-Faucher C. Biodiversity of lactic acid bacteria in French wheat sourdough as determined by molecular characterization using speciesspecific PCR. Int J Food Microbiol. 2009;135(1):53-9. [DOI:10.1016/j.ijfoodmicro.2009.07.006] [PMID]

21. Crowley S, Mahony J, Van Sinderen D. Comparative analysis of two antifungal $\mathrm{L}$ actobacillus plantarum isolates and their application as bioprotectants in refrigerated foods. J Appl Microbiol. 2012;113(6):141727. [DOI:10.1111/jam.12012] [PMID]

22. Rejiniemon TS, Hussain RR, Rajamani B. In-vitro functional properties of Lactobacillus plantarum isolated from fermented ragi malt. South Ind J Biol Sci. 2015;1(1):15-23. [DOI:10.22205/sijbs/2015/v1/i1/100437] 
23. Di Biase M, Lavermicocca P, Lonigro SL, Valerio F. Lactobacillus brevis-based bioingredient inhibits Aspergillus niger growth on pan bread. Ital J Agron. 2014;146-51. [DOI:10.4081/ija.2014.614]

24. Manini F, Casiraghi MC, Poutanen K, Brasca M, Erba D, Plumed-Ferrer C. Characterization of lactic acid bacteria isolated from wheat bran sourdough. LWT-
food Sci Technol.
2016;66:275-83.

[DOI:10.1016/j.lwt.2015.10.045]

25. Coda R, Cassone A, Rizzello CG, Nionelli L, Cardinali G, Gobbetti M. Antifungal activity of Wickerhamomyces anomalus and Lactobacillus plantarum during sourdough fermentation: identification of novel compounds and long-term effect during storage of wheat bread. Appl Environ Microbiol. 2011;77(10):3484-92. [DOI:10.1128/AEM.02669-10] [PMID] [PMCID]

26. Yan B, Zhao J, Fan D, Tian F, Zhang H, Chen W. Antifungal activity of Lactobacillus plantarum against Penicillium roqueforti in vitro and the preservation effect on Chinese steamed bread. J Food Process Preserv. 2017;41(3):e12969. [DOI:10.1111/jfpp.12969] 